\title{
A Descriptive Study of Motivationalvisitors at Batu Hobon Limbong Sagala-Samosir
}

\author{
Herdiana Boru Hombing \\ Institut Agama Kristen Negeri Tarutung \\ herdianasihombing@gmail.com
}

\begin{abstract}
This study aims to determine the motivation of visitors to the Batu Hobon Limbong Sagala Samosir tour. This research is a qualitative descriptive study because it produces descriptive data in the form of oral or written data, by looking for why or how something can happen. The research informant was determined by using accident sampling techniques, namely Batu Hobon tourist visitors as many as 10 people. Data collected through observation, interviews, and documentation are then described to obtain research objectives. Based on the results of the study, it was obtained that Batu Hobon visitors have diverse motivations coming to visit Batu Hobon, namely: recreational or recreational motivation, cultural and historical motivation, social-spiritual motivation, health motivation, and economic motivation. From this motivation, visitors to Batu Hobon visit, because they have unfulfilled desires and hope that by submitting a request to Mr. Sariburaja what they want, will be achieved. But some visitors come to Batu Hobon to travel or have fun and also to learn the history of Mr. Sariburaja and learn the Batak culture. If the arrival of visitors is based on the motivation of recreation and culturalhistorical motivation, visitors do not perform any ritual. But when a visitor's motivation comes with social-spiritual motivation, health and economics in all three indicate a desire to achieve and realize something, then the Hobon visitor will perform a ritual and offer a prayer and then offer up a sacrifice.
\end{abstract}

Keywords: motivation, visitors, Batu Hobon

\section{Preliminary}

Today travel has become a necessity for modern humans to break away from their daily routine as well as fulfill their spiritual needs and inner satisfaction. According to RI Law, number 10 of 2009 concerning Tourism Chapter 1 article 1 states that tourism is a travel activity carried out by a person/group of people by visiting certain places for recreational purposes, personal development or learning the uniqueness of tourist attractions visited in a temporary period visitors are people who come to tourist sites both individuals and groups with a variety of diverse motivations.

Motivation is a condition in an individual or organism that drives behavior toward the goal. A discussion of motivation will provide answers to the question "why does someone behave so". Concerning tourist visits, motivation is very important to be discussed to find out what exactly is behind the background of a person making a tour by visiting certain places. Various factors can influence a person to travel. Most people travel or traveled driven by the desire to have fun as a destination for tourists in general. But it is not uncommon for people to use their time to have fun while adding insight, knowledge, and skills about something. But someone can also visit tourist attractions because they are driven by both physical and psychological needs with the assumption that the place visited has the power that can provide 
what they want. (Pitayana and Gayatri,2005: 45) say that tourism motivation can be grouped into four major groups, namely as follows:

a) Physical or physiological motivation (motivation that is physical or physiological), among others for relaxation, health, comfort, participating in sports activities, relaxing, and so on.

b) Cultural motivation (cultural motivation), namely the desire to know the culture, customs, traditions, and arts of other regions. Also includes an interest in various cultural heritage objects or historic buildings. In the cultural motive that must be considered here is the cultural nature of the tourist motive, not its attractions. The attractions can be in the form of natural landscapes, flora, and fauna although tourists with cultural motives often come to tourist sites to learn or simply to get to know or understand the way of culture and culture of other nations or regions: their habits, daily life, culture in the form of buildings, music dance and so on.

c) Social motivation or interpersonal motivation (social motivation), such as visiting friends and family, meeting work partners, doing things that are considered to bring prestige (value of prestige), make pilgrimages, escape from boring situations, and so on. Many people assume that people who have visited other places naturally feel more than people who have never traveled. People who have traveled to other regions are considered or feel their prestige or status is higher.

d) Fantasy motivation (motivation due to fantasy), namely the existence of fantasy that in other areas a person can escape from the tedious daily routine, and ego-enhancement that provides psychological satisfaction. Also called status and prestige motivation. The motivation of one's journey is influenced by internal factors of the tourists themselves and external factors. Intrinsically, motivation is formed because of the needs and desires of humans themselves, according to Maslow's hierarchy of needs theory (Martin Handoko, 2008: 20). These needs start from biological needs, security needs, the need for love and belonging, the need for hope, the need to know, the need for beauty, and the need for self-actualization.

Extrinsic motivation is the motivation that is formed is influenced by external factors, such as social norms, influence, or family pressure and work situations that are internalized and then develop into psychological needs. The motivation of tourists to break away from routine activities serves to break away from routine activities to restore harmony in the community so that tourism can be seen as a form of social therapy.

Batu Hobon is a tourist attraction in the village of Limbong Sagala, Sianjur Mulamula, Samosir district. Named Batu Hobon of course with one reason that this stone is shaped like a Hobon (crate) and the lid is shaped love (Love). According to Batak beliefs, this stone is a cave-shaped tunnel and has a copy to various other places. Formerly in this place often held sacred ceremonies of respect to ancestral spirits that continue until now.

From the observations of researchers visitors who came to Batu Hobon Limbong Sagala tour not only enjoyed the Batu Hobon tourist area or studied the history of the origin of the Batak tribe, but also carried out rituals offering betel, eggs, kaffir lime, carrying flowers and also offering prayers. This has given rise to the anxiety of researchers so that what is the motivation of visitors coming to Batu Hobon?

Researchers suspect Batu Hobon tourist visitors have hidden motivations related to physical and spiritual issues that are not satisfied with their religious status. For example, the desire to have children, maintain rank and position, obtain healing, and spiritual thirst. For Christians, the above-mentioned fulfillment is obtained from God Almighty, the owner, and 
giver of everything. But in practice when what becomes human's needs and desires are not fulfilled in their religious life, people can look for other businesses to fulfill their needs, meant by visiting Batu Hobon tours and conveying their requests to Mr. Sariburaja. In connection with this, this research was formed with the aim of knowing the motivation of tourists in visiting Batu Hobon.

\section{Research Methodology}

This research is explorative (explorative research) which is also called as exploratory or exploratory research. This study agreed to find new problems to fill the void or lack of knowledge, both existing and existing. (Arief Subyantoro \& FX Suwarto,2007: 74) states that exploratory research aims to deepen the knowledge of a phenomenon to formulate a detailed problem.

This study uses a descriptive qualitative approach, according to Bogdan and Taylor in (Moleong,2007: 4), qualitative research is defined as a research procedure that produces descriptive data in the form of written or oral words from people and observed behavior. Moleong explained in a descriptive qualitative approach, the data collected was data in the form of words, pictures, and not numbers. The data can be obtained from interviews, field notes, videos, photos, and personal documentation. The results of this study are in the form of excerpts from interview transcripts that were previously processed and then presented descriptively. So qualitative research aims at interpreting social phenomena.

Research informants were determined by using accidental sampling techniques of tourists who came to Batu Hobon tourist attraction in the village of Limbong Sagala as many as 10 people, namely anyone who met with researchers at Batu Hobon attractions and was seen as suitable as a source of data and could be used as informants.

Data analysis in qualitative research was carried out since the researcher compiled the proposal, carried out data collection in the field until the researcher got all the data Afifuddin and Ahmad Beni Saebeni, (2012: 59). In data analysis techniques, there are four components in which the four components are a cyclical and interactive process in a study. The four components are:

\subsection{Data Collection}

Data collected by researchers in the form of data from interviews, observations, documentation recorded in field notes consisting of two aspects, namely description, and reflection. Description notes are natural data that contain what the researcher sees, hears, feels, witnesses, and experiences. Observations also include other data both verbal and nonverbal data from this study. Researchers will also take notes related to the reasons behind the tourists visiting Batu Hobon Limbong Sagala Samosir. Reflection notes are notes that make impressions, comments, and interpretations from researchers about the various findings that were found at the time of conducting research and are material for data collection plans for the next stage. To get this note, the researcher must conduct interviews with various informants.

\subsection{Data Reduction}

Data reduction is the process of selecting/simplifying the data obtained both from interviews, observations, and documentation based on the focus of the problem. After going 
through the data selection process, there will be important data and data that is not used. So, then the data is processed and presented in more scientific and meaningful language and writing.

\subsection{Data Presentation}

Presentation of data is the process of displaying data from all research results in the form of tabular representative narrative exposure including in the format of matrices, graphics and so on, which can later make it easier for researchers to see the results of research because of the large amount of data and information that researchers have difficulty in concluding the results of research this (Husni Usman, 2009: 85). The data obtained need to be presented in a simpler format so that researchers can easily analyze it and take actions based on the understanding obtained from the presentation of these data.

\section{Result and Discussion}

Batu Hobon is located at the foot of Pusuk Buhit, quite isolated from the surrounding communities, so it gives the impression of being lonely and authoritative. Surrounded by green and towering hills from the location of Batu Hobon, the village of Batak Sigulatti is visible. Located about 200 meters from the highway, it has a very wide location as a place for various activities such as parking vehicles, looking around, or just taking pictures. Batu Hobon itself is fenced around using natural stone as high as approximately 2 meters, and there is only one door as access for visitors in and out. In the location of the fence there is a large stone called Batu Hobon and in front of it is provided with a place to place offering materials such as betel, eggs, and kaffir lime. Besides, there are also smaller stones that can be used as a seat for Batu Hobon tour guides.

At the top stands majestically the statue of Ompu Tuan Saribu Raja and under the foot of the statue of Ompu Tuan Saribu Raja, it is usually the visitors put offerings and offer prayers. Based on observations and interviews conducted by researchers, it can summarize the various activities of Batu Hobon tourist visitors and the phenomena that appear as follows:

\subsection{Characteristics of Batu Hobon Visitors}

Batu Hobon Tourism is a tourist area that is intended for all people. This can be seen from the visitors who come to Batu Hobon tours from various age groups, children, adolescents, adults, and parents. On holiday visitors to Batu Hobon is busier than normal days and in general holiday visitors come in groups.

\subsection{Tourist Activities at Batu Hobon}

Batu Hobon is believed by tourists as a sacred place so that as far as possible tourists follow the rules made by officers in the place, for example before entering the location of the Batu Hobon building each tourist is required to take off shoes or sandals. Some tourists are open-hearted to clean up the location of Batu Hobon by sweeping the floor before performing rituals or prayers. After performing the ritual visitors usually observe the location of Batu Hobon. The duration of visitors in Batu Hobon is relatively short, especially if they do not perform any ritual, the duration is not more than 30 minutes, it can be longer if they do the 
ritual, but the duration is only 1 hour. Tourists can take food or drinks that have been offered by other visitors to Mr. Sariburaja by first asking permission from Mr. Sariburaja. In praying some tourists to close the gate of the Stone Hobon door, but there are also tourists who leave the gate open when praying.

\subsection{Ritual Implementation at Batu Hobon}

Tourist visitors who have the intention to submit a request or prayer, usually first offer offerings such as betel, eggs, bananas, drinks, gurgur, all of which are placed under the foot of the statue of Mr. Sariburaja. The ritual material to be offered can also be placed on ceramic plates that have been provided at the site but can also be placed directly on the stone around the statue of Mr. Sariburaja. The ritual materials are generally brought by visitors to Batu Hobon. After giving the offerings the visitor offers a prayer. Prayers can be said by visitors of tapai tourism can also be offered by datu or smart people brought by tourist visitors. The way to say the prayer below is by holding up the Hobon stone but if in the statue of Lord Sariburaja standing under the feet of Mr. Saribu Raja by folding the ladder, what prayer is said and to whom the prayer is addressed is unknown.

\subsection{Tour Visitor Motivation}

Tourism motivation is a desire to carry out in a concrete form, in the form of needs, encouragement, or certain reasons that make someone carry out tourism activities. In essence, the motives of people to travel are unlimited and cannot be limited. People make tourist visits based not only on one motivation but on a variety of interrelated motives. Based on the results of observations, interviews, and documentation, the motivation of visitors to Batu Hobon tourism can be described as follows:

\section{a) Motivation Recreation, having fun or sightseeing}

Batu Hobon visitors who come by not doing any rituals can be categorized as having recreational motivation, having fun, or sightseeing. They come to gather experiences and enjoy whatever interests them, such as natural landscapes, local customs, historical relics, monuments, the statue of Ompu Tuan Saribu Raja. Usually, when visitors are based on the motivation of recreation, fun, or sightseeing, they come in groups that can be in small numbers to large groups. Such motivation is believed to provide physical and spiritual freshness, restore physical fatigue that occurs as a result of routine every day, as well as gain experience from the activities carried out.

\section{b) Cultural-historical motivation}

Some visitors come to Batu Hobon want to learn about the culture of Batak customs, especially the history of the descendants of the Raja Batak Tuan Saribu Raja. Ending with such motivation also does not perform offering rituals, their activities draw more information from tour guides about the history of Batu Hobon and its use in the present by the Batak people. Such motivation increases the insight and knowledge of tourist visitors about the culture and history of Batak customs. 


\section{c) Social and Spiritual Motivation}

Many visitors come because they are driven by social and spiritual motivation. Visitors who are based on this motivation have an attachment to Saribu Raja, they are descendants of Saribu Raja called Limbong Mulana and Borbor Marsada. The arrival of Saribu Raja's descendants to Batu Hobon shows the existence of social ties and spiritual relations with their ancestors, therefore they view the arrival of Batu Hobon as a form of respect for the ancestors. Their activities are packaged with the term pilgrimage so that when they come they must bring flowers as proof of the attention to their ancestors. Opung is believed to have supernatural powers that exceed human strength as stated by (Jalaluddin,2008: 13) humans live in limitations and therefore their offspring can ask for help by maintaining and fostering good relations with ancestors. Then some offer prayers and supplications, such as a grandchild pleading to opung to be given what they need.

\section{d) Health Motivation}

Many of the visitors of Batu Hobon who come for health reasons, in the overall context of health motivation are referred to in the category of Physical or physiological motivation (motivation that is physical or physiological) as motivation for recreation, having fun, or sightseeing. Although in the modern world illness is no longer associated with spiritual symptoms, such as interference from evil spirits or spirits, there is still a growing belief that there is a sick disease whose healing process is not only obtained from the medical world but magical powers, the power of ancestral spirits. There are visitors to Batu Hobon who come directly to bring people who suffer pain, in this case, the sick person tells their request, but there are also those who ask for healing for their family or relatives who are sick who cannot visit Batu Hobon. Batu Hobon tourism visitors not only ask for healing for physical ailments but also psychological illnesses, for example, mental disorders, mental illness, and so forth. Although these health problems are difficult to understand logically, the information obtained is there, or maybe many visitors to Batu Hobon or their families have recovered from their illnesses after submitting their requests at Batu Hobon.

\section{e) Economic Motivation}

There is also the end that makes economic problems as motivation to perform offering rituals. The experience of deterioration and belief in the help of ancestral spirits that can show a way out of poverty and even provide prosperity and raise the level of life must be responded to faithfully visiting Batu Hobon tours. Loyalty to visit and offer this ritual is believed to be an effort to maintain an improved economic condition, bless the effort and work done to provide satisfactory results.

Every human being has certain basic needs that are needed for the process of his life to run smoothly. These needs can be in the form of physical, spiritual, or social needs. If these needs are not met, then humans will try to adjust to the reality they face. Furthermore, according to (Jalaluddin,2008: 166), one component that supports human adjustment is the depth of appreciation or religious religiosity. But if humans cannot resist the desire to fulfill their needs in such circumstances there will be contradictions or inner conflicts. This contradiction will cause spiritual imbalance to encourage someone to take actions that can deviate from the appreciation of religious values. 
In appreciation of Christian religious values, one of the main emphases in the interaction of daily life is a persistent and patient lifestyle. Biblical figures, such as Abraham in the Old Testament, Paul in the New Testament are very inspiring examples of perseverance, patience, and hope. There are many texts in the Bible about perseverance and patience, Paul's letters show some of them; Romans 5: 3-5 "And that's not all. We even boast in our misery because we know that misery causes perseverance and perseverance causes endurance and endurance causes hope ".

Based on the motivation described above, it appears that if visitors to Batu Hobon travel come because of recreational motivation, having fun or sightseeing, and cultural or historical motivation it does not conflict with the appreciation of religious values. But if the arrival of Batu Hobon visitors is driven by the desire to fulfill the needs of life both physically and psychologically, social and economic health then this shows the immaturity of religious appreciation, immaturity of religiosity which (Jalaluddin,2008: 246) can also be called a deviant religious attitude. Deviant religious attitudes can occur in all areas of human life with religious values. Deviations can be related to the field of beliefs, rituals, doctrines, or religious devices. On a higher scale, it can also give birth to new streams or revive old streams that are almost extinguished.

\section{Conclusions and Suggestions}

\subsection{Conclusion}

Based on the research results it can be concluded that:

a) Visitors to the Batu Hobon tour have various motives. These motivations include recreation motivation, fun or sightseeing, cultural or historical motivation, socio-spiritual motivation, health motivation and economic motivation.

b) These motivations include motivation for recreation, fun or sightseeing, cultural or historical motivation, social-spiritual motivation, health motivation, and economic motivation.

c) Visitors who come because of the motivation for recreation, having fun or sightseeing and because of cultural or historical motivation who only want to learn about Batu Hobon attractions do not perform any rituals and also do not offer prayers and requests.

d) Visitors who come to Batu Hobon because they are motivated by social-spiritual motivation, health, and economy have the assumption that the ancestors have the power or sahala that can fulfill their needs and grant their wishes. Therefore visitors who attend due to the motivation usually perform rituals by offering betel, eggs, kaffir lime, flowers, bananas, and so on. This category also offers prayers and requests that can be made by shamans in Limbong Sagala or shamans they bring themselves.

e) Visitors who come to Batu Hobon because of the motivation mentioned above indicate a lack of appreciation of religious values which can develop into an attitude of religious deviation.

f) Batu Hobon tourism can be categorized as religious tourism or spiritual tourism, because Batu Hobon tourism visitors believe in the existence of a supernatural essence, a power that exceeds human power, which can answer their prayers and requests. 


\subsection{Suggestion}

a) Church ministers should improve their ministry amid the congregation to equip them to address various problems of life and live the theology of hope in the congregation.

b) It is recommended that local churches in the Limbong Sagala region initiate cooperation with the Regency government to provide spiritual service facilities at tourist sites to minimize religious deviations.

c) It is recommended to the local government to preserve Batu Hobon as a cultural and historical tourism object.

d) It is recommended to the next researcher to conduct research related to one specific motivation

\section{References}

[1] Arikunto,S,2002, ProsedurSuatuPenelitian : SuatuPendekatanPraktek, Jakarta : PT RinekaCipta,

[2] AviyahEvi dan Muhammad Farid, 2014, :"Religiusitas, KontrolDiri dan KenakalanRemaja" dlm Persona Jurnalpsikologi Indonesia

[3] Drikarya N, 1987, PercikanFilsafat, (PT Pembangunan, Jakarta)

[4] Handoko, Martin, 1992, MotivasiDayaPenggerakTingkahLaku (Kanisius, Yogyakarta)

[5] Hutagalung, WM, 1926, Pustaha Batak, TaromboDohotTuriturianniBangso Batak, Tulus Jaya, Medan

[6] Jalaluddin, 2008, Psikologi Agama, Raja Grafindo

[7] Mangunwijaya, Y.B. 1986, MenumbuhkanSikapReligius Anak, Gramedia, Jakarta

[8] Moleong, Lexy J, 2007, MetodologiPenelitianKualitatif, Bandung : PT RemajaRosdakaryaOffset

[9] Pitayana dan Gayatri, 2005, SosiologiPariwisata, Andi Publisher, Yogyakarta

[10] SyukurDister Nico, 1982, Pengalaman dan MotivasiBeragama, Lepenas, Jakarta

[11] Sugyono,2007, MetodePenelitianKuantitatif, Kualitatif dan R\&D,

[12] Subyantoro, Arief\&FX.Suwarto, 2007, Metode\& Teknik Penelitian Sosial, Andi Offset, Yogyakarta

[13] Wahab,S, 2003, ManajemenKepariwisataan, Pandya Parawita, Jakarta 